\title{
高速液体クロマトグラフィーによる軟こう中の副じん皮質 ホルモン及びパラベンの同時定量
}

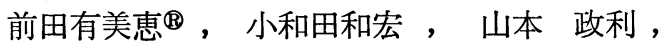 \\ 佐野 智子，増井 俊夫*，中澤 裕之**
}

(1988 年 6 月 28 日受理)

HPLG により，軟こう中の 11 種類の副じん皮質ホルモン及び 4 種類のパラベンを一斉分析する方 法を確立した．試料の前処理として，軟こう中の基郕を除去するためにディスポーザブルの Sep-Pak シリカゲルカートリッジを用いたクリーンフップを行った．HPLGの条件は，カラム：Inertsil ODS-2,

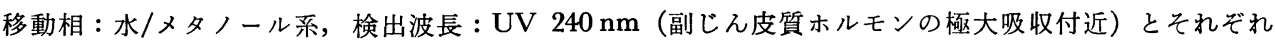
設定することにより，良好な分離が得られた。定量は $s$-ブチルパラベンを内標準物質として用いる内 標準法により行った．検量線は副じえ皮質ホルモンについては 2〜100 $\mu \mathrm{g} / \mathrm{ml}$ ，パラベンについては 1〜 $50 \mu \mathrm{g} / \mathrm{ml}$ の濃度範囲でいずれも原点を通る良好な直線性を示した．添加回収実験の結果は回収率，精 度ともに良好であった。本法は簡便な前処理により副じん皮質ホルモン及びパラベンを迅速・正確に一 斉分析できることから日常分析法として有用な方法である.

\section{1 緒言}

副じん皮質ホルモン（以下 GCS と略記）を含有する 製剂は，抗炎症作用や免度賦活作用など種々の薬理効果 を有する治療薬として多くの臨床分野ではん用されてい る. しかしこれらの効果を期待する CCS の薬理学的量 は, 各種代謝系への CCS の異化作用の増大を伴い, 又 感染に対する抵抗性減弱などの副作用をる有する1).

一方 CCS には軟こう中で不安定であることが報告さ れている2) ものもあり, 製郕の品質を確保するうえで主 成分である CCS の含有量を正確に把握する必要があ る. 従来 CCS の定量に用いられていた比色法3) や蛍光 法4)は，同じ官能基を有する分解物や不純物などの類縁 物質が共存する場合に，これらとの分離定量が困難であ った. 近年, 操作性や定量性に優れた HPLC が CCS の分析にも応用されるようになった。これまでの CCS に関する HPLC による報告をみると，単一成分につい ては ODS カラムを用いた分析法が日本薬局方5 にも幾 つか収載されているが，多成分を一斉分析する場合に

* 静岡県衛生環境センター：420 静岡県静岡市北安 東 4-27-2

** 厚生省国立公衆衛生院：108 東京都港区白金台 46-1
は，シリカゲルを固定相とする順相クロマトグラフィ 一6)7) やスチレンージビニルベンゼン系ポーラスポリマ 一を充てん㶡として用いた方法8) が主体であった，又， 軟こうや眼軟こうにおいては防腐剤としてパラベンが処 方されている例が多いが, CCS 及びパラベンを一斉分析 するHPLG 法はこれまでにほとんど報告されていない.

そこで今回, 軟こう中の 11 種類の CCS 及び 4 種類 のパラベンの一斉分析に， はん用性の高い逆相系 ODS カラムを用いた HPLG 分離条件の検討を行った. 又, 軟こう中に含まれる基剈などの共存物質を除去するため に，ディスポーザブルのシリカゲルカートリッジを用い た簡便なクリーンアップ方法についても検討し，良好な 結果を得たので併せて報告する.

\section{2 実験方法}

\section{1 試 料}

GCS 含有軟こう 16 検体を試料とした。

\section{2 試番}

GGS 標準品：プレドニゾロン (PR), フルオシノロン アセトニド (FA), トリアムシノロンフセトニド (TA), 酪酸ヒドロコルチゾン (HB) 及び吉草酸ベタメタゾン (BV) は日本薬局方品を用いた. 又フルオシノニド (FL), ジフルプレドナート (DF), 吉草酸デキサメタゾ 
$(\mathrm{DX})$, 吉草酸酢酸プレドニゾロン $(\mathrm{PV})$, プロピオ ソ酸 ヘクロメタゾン (BD) 及び吉草酸ジフルコルトロ ン (DV) は標準品として製薬会社から供与されたもの を用いた.なお，これらの標準品は日本薬局方5) 又は製 薬会社の標準品規格に従って乾燥後使用した。

CGS 標準原液：各 CGS 標準品約 $100 \mathrm{mg}$ を精ひょ うし，それぞれメタノールに溶解して正確に $100 \mathrm{ml}$ と したものを各 CGS 標準原液とした.

パラヘン標準品：メチル，エチル，n-プロピル及び $n$ ブチルパラベンは東京化成工業製特級品を日本薬局方5)

に従って乾燥後用いた.

パラベン標準原液 : 各パラペン標準品約 $100 \mathrm{mg}$ を精 ひょうし，それぞれメタノールに溶解して正確に $100 \mathrm{ml}$ としたものを各パラベン標準原液とした.

内標準溶液 : $s$-ブチルパラヘン（東京化成工業製, 試 薬特級品）約 $50 \mathrm{mg}$ を精ひょうし，メタノールに溶解 して $100 \mathrm{ml}$ としたものを内標準溶液とした。

カートリッジ：ディスボーザブルの Sep-Pak シリカ ゲルカートリッジ（Waters 製）を用いた.

モデル基戍：日本薬局方5) の軟こう郕の項に従い，流 動パラフィン $10 \mathrm{~g}$ 及び白色ワセリン $90 \mathrm{~g}$ を混和して調 製した。

\section{$2 \cdot 3$ 装 置}

HPLG：日立製作所製 635 型液体クロマトグラフに 島津製作所製紫外部吸収検出器 SPD-2A 型, ガスクロ 工業製カラムオーブン 555 型及び協和精密製オートサン プラー KSST-601 型を装着したものを用いた.

振り混ぜ器 : イワキ製 V-S 型

冷却遠心分離機 : 日立工機製 SGR-20BA 型

超音波浴槽 : 国産電気製 UT-6 型

ロータリーエバポレーター：東京理化器械製 N-1 型

\subsection{HPLC 条件}

カラム : Inertsil ODS-2 $(5 \mu \mathrm{m}, 4.6 \mathrm{~mm}$ i.d. $\times 150$ $\mathrm{mm}$ ，ガスクロ工業製)

カラム温度 : $40^{\circ} \mathrm{C}$

移動相A：メタノール/水 $(50: 50) ; \mathrm{PR}, \mathrm{TA}, \mathrm{FA}$ 及びパラベン (メチル，エチル，n-プロピル及び $n$-ブチ ル）分析用

移動相 B : メタノール/水 $(60: 40) ; \mathrm{HB}, \mathrm{FL}, \mathrm{DF}$, $\mathrm{DX}, \mathrm{BV}, \mathrm{PV}, \mathrm{BD}, \mathrm{DV}$ 及びパラベン (メチル, エチ ル，n-プロピル及び $n$-ブチル）分析用

流速 : $0.7 \mathrm{ml} / \mathrm{min}$

検出波長及び感度 : UV $240 \mathrm{~nm}, 0.04$ AUFS

試料注入量 : $10 \mu 1$

\section{5 試験溶液の調製}

軟こら $1.0 \mathrm{~g}$ を精ひょらしテトラヒドロフラン $5 \mathrm{ml}$ 及び内標準溶液 $1 \mathrm{ml}$ を加え 5 分間激しく振り混ぜて溶
解し, メタノール $15 \mathrm{ml}$ を加えて混和後しばらく放置す る.これを冷却遠心分離 $\left(5000 \mathrm{rpm}, 5 \mathrm{~min}, 0^{\circ} \mathrm{C}\right)$ し， この上澄み液 $10 \mathrm{ml}$ をとり減圧下 $30^{\circ} \mathrm{C}$ で溶媒を留去 し, 乾固する. 残留物にへキサン/クロロホルム (70: 30） $10 \mathrm{ml}$ を添加し超音波浴槽内で溶解させた後, その $4 \mathrm{ml}$ をカートリッジに通す。 このカートリッジをへキ サン/クロロホルム $(70: 30) 10 \mathrm{ml}$ で洗浄した後, カ ートリッジに吸着された CGS 及びパラベンを酢酸ェチ ル $10 \mathrm{ml}$ で溶出させる. 溶出液の溶媒を減圧下 $30^{\circ} \mathrm{C}$ で留去後, メタノール $10 \mathrm{ml}$ に溶解し, 試験溶液とす る.

\section{6 検量線の作成}

各 CGS 標準原液及び各パラベン標準原液を混合し, これに内標準溶液 $1 \mathrm{ml}$ を添加した後, CCS の濃度が $0.002 \sim 0.100 \mathrm{mg} / \mathrm{ml}$, パラベンの 濃度が $0.001 \sim 0.050$ $\mathrm{mg} / \mathrm{ml}$ となるよらにメタノールで希釈して各標準溶液 を調製する.これらの標準溶液には $0.01 \mathrm{mg} / \mathrm{ml}$ の濃度 の内標準物質が含有される，各標準溶液を HPLC に供 し, 内標準物質に対する GCS 及びパラベンの面積比よ りそれぞれの検量線を作成する。

\section{3 結果及び考察}

\subsection{HPLC 測定条件の検討}

鎌田ら?)はカラム充てん剤として逆相系 ODS の Fine Pack SIL G18 を用いた場合, 移動相の 比率を变化さ せても CCS の分離が不十分であり, 順相系の Zorbax SIL のほらが良好な分離能を示すことを報告している. 又, 江島ら ${ }^{8)}$ はパラベンが配合された場合にはシリカゲ ル又はニトリル系化学結合型シリカゲル，あるいはポー ラスポリマーを充てん剂として用いる必要があることを 報告している.

著者らは充てん剂として一般によく用いられる逆相系 ODS により CCS 及びパラベンの一斉分析を行らこと を目的に, Inertsil ODS-2 カラムを用いて分離条件を 検討した.

3.1.1 移動相の検討 移動相としてメタノール/水 系及びアセトニトリル/水系の両者について検討したと ころ, 個々の CGS とパラベンの分離を考慮した場合に アセトニトリル/水系ではメチルパラベンとプレドニゾ ロンが分離しなかった. しかし，メタノール/水系では これらが十分に分離したので以後メタノール/水系を用 いることにした.

メタノール/水系の移動相に打ける溶出順序により, CCS は $n$-ブチルパラベンよりる早く溶出するグループ 
A (PR, TA 及び FA) と, n-ブチルパラベンよりも遅 く溶出するグループ B (HB, FL, DF, DX, BV, PV, $\mathrm{BD}$ 及び DV) との二つに大別された. これら二つのグ ループに対する最適な移動相条件を求めるために, 移動 相中のメタノール濃度が CGS 及びパラベンの capacity factor $\left(k^{\prime}\right)$ に及ぼす影響について 検討し，その結果の 一部を Fig. 1 に示した。極性の大きいグループ A の CCS はメタノール 60\% 以上で PR 及びェチルパラベ ンの 2 成分, 又 TA, FA 及び $n$-プロピルパラベンの 3 成分がそれぞれ 重なった。 しかしメタノール 50\% （移動相A）の条件でこれらは相互に十分分離された. 一方, 極性の小さいグループ B の CCS はメタノール $50 \%$ では $k^{\prime}$ が非常に大きいため分析に長時間を要する が，逆にメタノール 70\% では HB，FL 及び DF の保 持時間が近似し分離が不十分であった。しかしメタノー ル 60\% (移動相 B ) の場合には分離, 保持時間ともに 良好であった. 以上のことより, はん用性の高い逆相系 の ODS カラムを用い, 移動相 A, B の 2 条件で, 11 種類の CGS 及び 4 種類のパラベンを良好に分離するこ とができた。

3.1.2 測定波長の選定 各 CCS の移動相溶液に おける 紫外部吸収スペクトルの 極大はすべて $237 \sim 243$

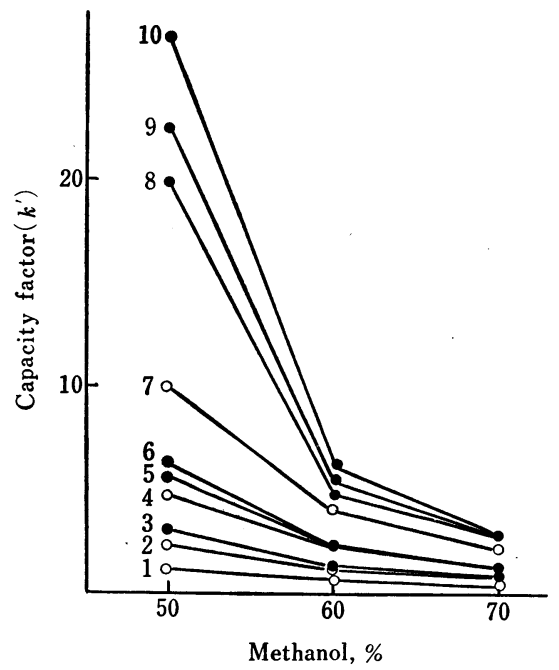

Fig. 1 Effect of methanol concentration in mobile phase on capacity factors of corticosteroids (O) and parabens (O)

1 : methylparaben, 2 : ethylparaben, 3 : prednisolone, $4: n$-propylparaben, $5:$ triamcinolone acetonide, $6:$ fluocinolone acetonide, 7 : $n$-butylparaben, 8 : hydrocortisone butyrate, 9 : fluocinonide, $10:$ difluprednate $\mathrm{nm}$ の領域にあり，又パラベンの極大吸収波長は 257 $\mathrm{nm}$ 付近であった．そこでそれぞれの分子吸光係数及び 軟こう中の配合量を考慮して測定波長を $240 \mathrm{~nm}$ に設定 した.

3.1.3 内標準物翼の検討 本法を軟こう製剤に 適 用した場合に予想される前処理及び定量操作に伴う誤差 を少なくし，分析精度を向上させる目的で内標準法を用 いることにした．内標準物質として軟こうに配合される ことのない化合物について検討した結果, 化粧品中のパ ラベンの定量9において内標準物質として使用した $s$-ブ チルパラベンが, 移動相 A，B いずれの条件においても 適当であった．以上の検討の結果，得られた標準溶液の クロマトグラムを Fig. 2 及び Fig. 3 に示した。

\section{2 検量線}

各 CGS については $0.002 \sim 0.100 \mathrm{mg} / \mathrm{ml}$, 又各パラ ベンについては $0.001 \sim 0.050 \mathrm{mg} / \mathrm{ml}$ の濃度範囲に拈い て，いすれも原点を通る良好な直線関係 $(r>0.999)$ が 得られた。な打本法による検出限界は各 CGS $2 \mathrm{ng}$, 各 パラベン $1 \mathrm{ng}$ であった.

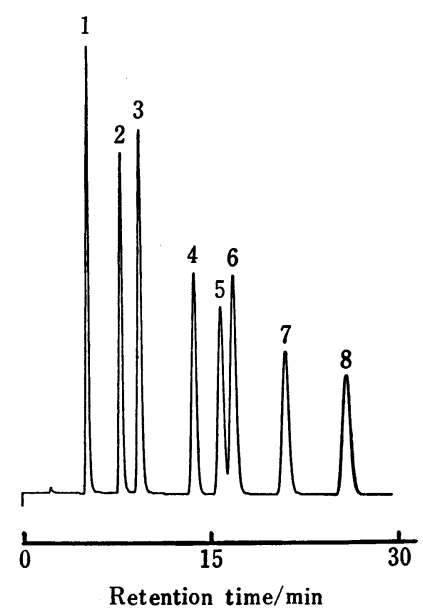

Fig. 2 Liquid chromatogram of corticosteroids (group A) and parabens in standard solution

Peak-1 : methylparaben, 2 : ethylparaben, 3 : prednisolone, $4: n$-propylparaben, $5:$ triamcinolone acetonide, 6 : fluocinolone acetonide, $7:$ internal standard ( $s$-butylparaben), $8: n$-butylparaben; Column : Inertsil ODS-2 $(5 \mu \mathrm{m}, 4.6 \mathrm{~mm}$ i.d. $\times 150 \mathrm{~mm})$; Column temperature : $40^{\circ} \mathrm{C}$; Mobile phase : methanolwater $(50: 50)$; Flow rate $: 0.7 \mathrm{ml} / \mathrm{min}$; Detection : UV $240 \mathrm{~nm}$ (0.04AUFS) 


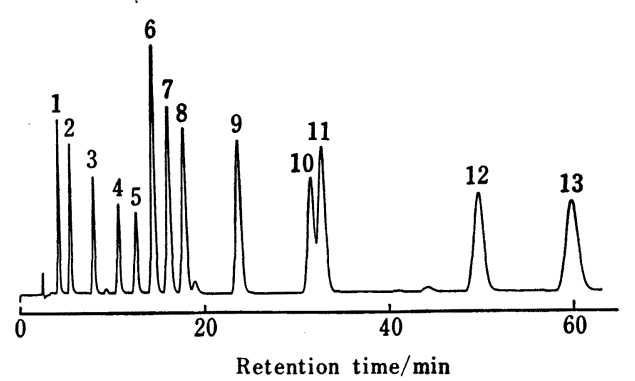

Fig. 3 Liquid chromatogram of corticosteroids (group B) and parabens in standard solution

Peak-1: methylparaben, $2:$ ethylparaben, $3: n$-propylparaben, $4:$ internal standard $(s-$ butylparaben), $5: n$-butylparaben, $6:$ hydrocortisone butyrate, $7:$ fluocinonide, $8:$ difluprednate, $9:$ dexamethasone valerate, 10 : betamethasone valerate, $11:$ prednisolone valerate-acetate, 12 : beclomethasone dipropionate, 13 : diflucortolone valerate; Mobile phase : methanol-water $(60: 40)$; Other conditions as shown in Fig. 2.

\section{3 シリカゲルカートリッジを 用いた 前処理方法の}

\section{検討}

軟こう中に共存する基剤などの成分は HPLG 分析時 にカラムを劣化させたり CCS の定量を妨害するおそれ がある，これまでに，基剤などの成分を除去するためア セトニトリルーヘキサン分配7) やカラムクロマトグラフ イー10)によるクリーンアップ方法が報告されているが, これらの方法は煩雑な抽出やカラムの調製が必要であ る. そこで, 簡便な前処理方法についてモデル基剤を用 いて以下検討した. 冷却下遠心分離することにより重量 比で約 85\% の基剤を除去することができたが，残りの $15 \%$ を除去するためにディスポーザブルのシリカゲル カートリッジを用いることにした． モデル基剤に CCS 及びパラベンを添加し，2.5 に示した方法により得た残 留物の溶解溶媒, 更に基剤などの 共存成分を 除去する カートリッジの洗浄溶媒として, ヘキサン/クロロホル ムの混合溶媒を用いて $(80: 20) \sim(50: 50)$ まで種々の 組成を検討した. その結果, 溶解溶媒及び洗浄溶媒とし てへキサン/クロロホルム $(65: 35)$ を用いた場合には $15 \mathrm{ml}$ で $n$-ブチルパラベンが溶出しはじめたが，(70： 30）を用いた場合， $15 \mathrm{ml}$ までカートリッジを洗浄して も各 CGS 及びパラベンが溶出しなかった. そこで, 残 留物の溶解及び洗浄にへキサン/クロロホルム (70:30) の溶媒を用いることにし, その洗浄液量は $10 \mathrm{ml}$ とし た. 更にカートリッジに吸着された CCS 及びパラベン
の溶出溶媒についてもへキサン/クロロホルム，クロロ ホルム, クロロホルム/酢酸エチル, 酢酸エチル, 酢酸 エチル/メタノールの 5 種類の溶媒について 検討した. 前三者の溶媒では PR をはじめとする成分の溶出が不十 分であったが，酢酸エチルを用いた場合には全成分が完 全に溶出した.なお, 酢酸エチル/メタノールでは基剤 から不明成分の溶出が見られた. そこで溶出溶媒として 酢酸エチルを用いることにした. その溶出パターンの一 部をFig. 4 に示した.なお，その溶出液量については， 最も早く溶出する $n$-ブチルパラベンは $2 \mathrm{ml}$ で十分であ ったが，最も遅く溶出する PR は $8 \mathrm{ml}$ 必要であった。 そこで GCS 及びパラベンを完全に溶出させるために溶 出液量は $10 \mathrm{ml}$ とした.

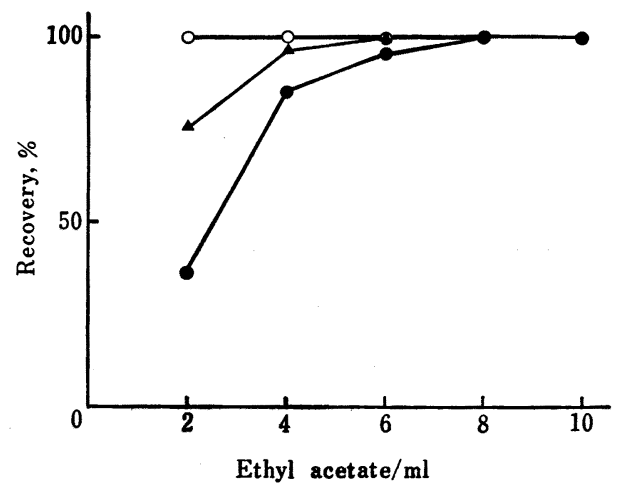

Fig. 4 Elution patterns of prednisolone (O), hydrocortisone butyrate $(\boldsymbol{\Delta})$ and $n$-butylparaben (O) on Sep-Pak silicagel cartridge

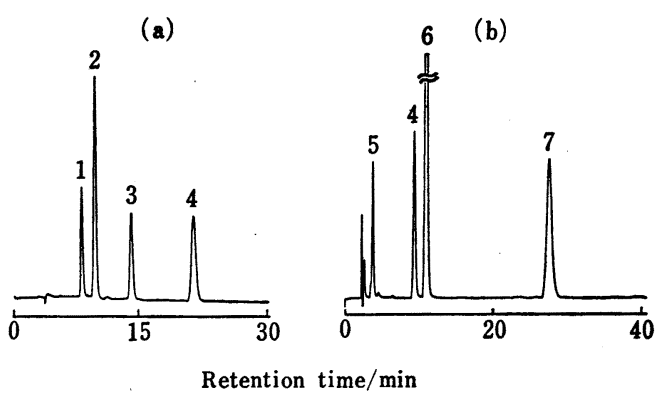

Fig. 5 Liquid chromatograms of extracts from ointments (a) and (b)

Peak - 1: ethylparaben, 2 : prednisolone, 3 : $n$-propylparaben, $4:$ internal standard( $s$-butylparaben), 5 : methylparaben, $6: n$-butylparaben, 7 : betamethasone valerate; Conditions (a) as shown in Fig. 2, (b) as shown in Fig. 3. 
Table 1 Recoveries of corticosteroids and parabens from ointment base

\begin{tabular}{lcccc}
\hline \multicolumn{1}{c}{ Compounds } & $\begin{array}{c}\text { Amount added/ } \\
\mathrm{mg} \mathrm{g}^{-1}\end{array}$ & $\begin{array}{c}\text { Amount found/ } \\
\mathrm{mg} \mathrm{g}^{-1}\end{array}$ & $\begin{array}{c}\text { Recovery, } \\
\%\end{array}$ & $\begin{array}{c}\text { R. S. D., } \\
\%\end{array}$ \\
\hline Methylparaben & 0.50 & 0.500 & 100.1 & 0.4 \\
Ethylparaben & 0.50 & 0.496 & 99.3 & 0.8 \\
$n$-Propylparaben & 0.50 & 0.492 & 98.4 & 0.6 \\
$n$-Butylparaben & 0.50 & 0.497 & 99.4 & 0.7 \\
Prednisolone & 1.0 & 1.025 & 102.5 & 1.3 \\
Triamcinolone acetonide & 1.0 & 1.032 & 103.2 & 0.9 \\
Fluocinolone acetonide & 1.0 & 0.988 & 98.8 & 1.5 \\
Hydrocortisone butyrate & 1.0 & 1.023 & 102.3 & 1.5 \\
Floucinonide & 1.0 & 1.024 & 102.4 & 1.6 \\
Difluprednate & 1.0 & 1.022 & 102.2 & 1.6 \\
Dexamethasone valerate & 1.0 & 1.019 & 101.9 & 1.4 \\
Betamethasone valerate & 1.0 & 0.990 & 99.0 & 1.5 \\
Prednisolone valerate-acetate & 1.0 & 1.026 & 102.6 & 2.4 \\
Beclomethasone difluprednate & 1.0 & 1.011 & 101.1 & 2.2 \\
Diflucortolone valerate & 1.0 & 1.022 & 102.2 & 1.8 \\
\hline
\end{tabular}

Average of five experiments; R.S. D. : relative standard deviation

Table 2 Analytical results of corticosteroids (GGS) and parabens in commercial ointments

\begin{tabular}{rlccccc}
\hline $\begin{array}{c}\text { Ointment } \\
\text { No. }\end{array}$ & Kinds of CCS & $\begin{array}{c}\text { Contents of CCS/ } \\
\mathrm{mg} \mathrm{g}^{-1}\end{array}$ & \multicolumn{3}{c}{ Contents of paraben/mg $\mathrm{g}^{-1}$} \\
\cline { 5 - 7 } & Methyl & Ethyl & $n$-Propyl & $n$-Butyl \\
\hline 1 & Prednisolone & 5.140 & 0.433 & $*$ & $*$ & 0.957 \\
3 & Prednisolone & 5.065 & $*$ & 0.963 & 0.962 & $*$ \\
4 & Triamcinolone acetonide & 1.026 & $*$ & $*$ & $*$ & $*$ \\
5 & Fluocinolone acetonide & 0.258 & $*$ & $*$ & $*$ & $*$ \\
6 & Hydrocortisone butyrate & 1.073 & $*$ & $*$ & $*$ & $*$ \\
7 & Fluocinonide & 0.513 & $*$ & $*$ & $*$ & $*$ \\
8 & Fluocinonide & 0.506 & $*$ & $*$ & $*$ & $*$ \\
9 & Fluocinonide & 0.500 & 0.480 & $*$ & 0.474 & $*$ \\
10 & Difluprednate & 0.518 & $*$ & $*$ & $*$ & $*$ \\
11 & Dexamethasone valerate & 1.180 & $*$ & $*$ & $*$ & $*$ \\
12 & Dexamethasone valerate & 1.180 & $*$ & $*$ & $*$ & $*$ \\
13 & Betamethasone valerate & 1.271 & 1.016 & $*$ & $*$ & 1.010 \\
14 & Betamethasone valerate & 1.228 & 0.206 & $*$ & $*$ & 1.753 \\
15 & Prednisolone valerate-acetate & 2.913 & 0.098 & $*$ & 0.106 & $*$ \\
\end{tabular}

* less than $0.025 \mu \mathrm{g} / \mathrm{g}$

このように冷却遠心分離やカートリッジを用いた精製 などの一連の前処理操作により, 基䠼をほとんど除去す ることができた。

\section{4 添加回収実験}

2.2 のモデル基剤に CCS 及びパラベンを添加し 5 回 繰り返し測定して回収実験を行ったところ, Table 1 に 示すよらに回収率は 98.4～103.2\%，相対標準偏差は $2.4 \%$ 以下と良好な結果が得られた. 本法は簡便な前処 理により, 正確で精度の高い CCS 及びパラベンの定量 が可能であることが確認された.

\section{5 実試料の分析結果}

軟こう製剤 16 検体の分析に本法を適用したところ, 他成分の 影響を受けることなく良好なクロマトグラム (Fig. 5) が得られた。 これら実試料の分析結果を Table 2 に示した. なお, CCS の表示量は 0.25〜 $5 \mathrm{mg} / \mathrm{g}$ の範囲にあったが，実際の 分析値は表示量の 96.4〜 $107.3 \%$ であった. 又パラベンは 6 検体から検出され, メチル, エチル, $n$-プロピル, $n$-ブチルの 4 種類がそれぞ れ 2 種類ずつの組み合わせで使用されていた.

以上, 基㶡などの脂溶性物質を除去するためディスポ 
ーザブルのシリカゲルカートリッジを用いた簡便な前処 理を行った後に, はん用性の高いODS カラム, 水一メ タノール系の移動相を用いた HPLG に供し，s-ブチル パラベンを内標準物質として定量することにより，軟こ う中の 11 種類の CCS 及び 4 種類のパラベンを迅速簡 便かつ正確に同時定量することができた. 本法を軟こう 製剂に適用したところ，いずれも他成分の影響を受ける ことなく良好に分析でき，軟こう中の CGS 及びパラべ ンの一斉日常分析法として有用であることが確認され た.

\section{交献}

1) 竹田亮祐：日本医師会雑誌，96, 1145 (1987).

2) 上原真一, 宮竹ノリエ, 重岡捨身, 風間成孔, 秋 山和幸 : 東京衛研年報, 33, 90 (1982)。

3) 中路幸男, 太田美矢子, 早川墓男, 川村次良 : 医 薬品研究, 7, 17 (1976).

4) 德永裕司, 木村俊夫, 川村次良 : 薬学雑誌, 100, 200 (1980).

5) 厚生省：第十一改正日本薬局方，p. 19，(1987).

6) 増川健二, 清水能治, 宮本尚明, 藤本雄三, 津曲 喜雍 : 医薬品研究, 16, 78 (1985).

7) 鎌田国広, 観 照雄, 吉原武俊, 原田裕文: 衛生 化学, 28, 341 (1982).

8) 江島 昭, 立沢政義, 松田りえ子: 医薬品研究, 15, 118 (1984).

9) Y. Maeda, M. Yamamoto, K. Owada, S. Sato, T. Masui, H. Nakazawa and M. Fujita : $J$. Chromatogr., 410, 413 (1987).

10) 德永裕司, 木村俊夫, 川村次良：医薬品研究, 15, 87 (1984).
Simultaneous determination of corticosteroids and parabens in ointments by HPLC. Yumie Maeda, Kazuhiro Owada, Masatoshi Yamamoto, Satoko Sano, Toshio Masur* and Hiroyuki NakazAWA** (*Shizuoka Prefectural Institute of Public Health and Environmental Science, 4-27-2, Kitaando, Shizuoka-shi, Shizuoka 420; **The National Institute of Public Health, 4-6-1, Shirokanedai, Munato-ku, Tokyo 108)

A rapid, simple and reliable method was developed for the simultaneous determination of eleven corticosteroids, such as prednisolone, triamcinolone acetonide, fluocinolone acetonide, hydrocortisone butyrate, fluocinonide, difluprednate, dexamethasone valerate, betamethasone valerate, prednisolone valerate-acetate, beclomethasone dipropionate and diflucortolone valerate, and four parabens, such as methyl, ethyl, $n$ propyl and $n$-buthylparaben in ointments by HPLC. The method involves a clean-up on a disposable SepPak silicagel cartridge. Fat-soluble excipients are removed through the cartridges with $10 \mathrm{ml}$ of hexanechloroform $(70: 30)$. Corticosteroids and parabens are then eluted from the cartridges with $10 \mathrm{ml}$ of ethyl acetate and determined by HPLC on a reversed-phase column with water-methanol $(50: 50$ and $60: 40)$ as the mobile phase, and detected at $240 \mathrm{~nm}$ with 0.04AUFS using $s$-butylparaben as an internal standard. The method was successfully applied to the analysis of ointement base spiked corticosteroids and parabens, and the sufficient recoveries $(98.4 \sim 103.2 \%)$ were obtained with relative standard deviation of $0.4 \sim 2.4 \%$.

(Received June 28, 1988)

\section{Keyword phrases}

simultaneous determination of corticosteroids and parabens in ointment; reversed-phase HPLG; pretreatment with disposable silicagel cartridge. 